\title{
La revisión judicial de las sanciones eléctricas
}

\section{Judicial review of electric administrative sanctions}

Pablo Méndez Ortiz

Este trabajo aborda el sistema de revisión judicial de sanciones administrativas eléctricas: uno de revisión cerrada, según la jurisprudencia de la Corte Suprema. Este sistema, con sus deficiencias, cuenta con algunas ventajas: evita ficción institucional y duplicación de esfuerzos, siendo más coherentes que sistemas de otras áreas.

Palabras clave: Revisión judicial, Sanciones eléctricas, Ley $N^{\circ} 18.410$.
This Article addresses the model of judicial review of the electric administrative sanctions-a closed review model according the Supreme Court decisions. This model has certain institutional advantages: avoids institutional friction between the agency and the court as well as duplication of efforts, being more coherent than models from other areas.

Keywords: Judicial review, Electric sanctions, Law $\mathrm{N}^{\circ} 18,410$.

\section{Introducción}

Tras la promulgación de la Constitución de 1980, la mirada a la potestad sancionadora de la Administración del Estado ha pasado por diversas etapas en la cultura jurídica nacional ${ }^{1}$. Una primera fase, de negación (en los años ochenta), se oponía a la entrega de facultades sancionatorias por vía legal a organismos administrativos, bajo la idea que sancionar era equivalente a ejercer actividades jurisdiccionales. Tras ello, devino una segunda etapa de aceptación (en los años noventa), que conllevó un reconocimiento de la necesidad de instaurar límites a

\footnotetext{
Profesor Invitado, Escuela de Derecho, Universidad Alberto Hurtado. Licenciado en Derecho, Universidad de Valparaíso (Chile), Master en Derecho, New York University (Estados Unidos). Correo electrónico: pmo231@nyu.edu. Dirección postal: Cienfuegos 41, Comuna de Santiago, Chile. Una versión previa del argumento de este trabajo fue presentada el 12 de agosto de 2020 en las XX Jornadas de Derecho de la Energía de la Pontificia Universidad Católica de Chile. La elaboración de este trabajo se ha visto beneficiada como parte del Proyecto FONDECYT Regular N 1201783, del cual el autor es coinvestigador. 1 En la caracterización de estos tres periodos dentro del Derecho chileno sigo a Soto DeLGADO 2018, 9; y LARROCAU TORRES 2015.
}

Artículo recibido el 2 de marzo de 2021 y aceptado el 8 de noviembre de 2021. 
esta potestad. En el medio chileno, estos límites fueron invocados a través de la idea del "ius puniendi" único a nivel estatal. Hoy en día, por último, nos encontramos en un periodo reflexivo sobre el diseño institucional que conlleva el ejercicio de potestades sancionatorias, incluyendo también una reflexión acerca de la posterior revisión judicial a través del contencioso-administrativo.

El periodo de reflexión en que nos encontramos no solo se concentra en aquellos procesos más nuevos (por ejemplo, la reforma al mercado de valores de la Ley $\mathrm{N}^{\circ} 21.000$, o la instaurada en medio ambiente con las Leyes $\mathrm{N}^{\circ} 20.417$ y $\mathrm{N}^{\circ} 20.600$ ), sino que alcanza incluso a aquellas potestades sancionadoras y contenciosos-administrativos más antiguos. Es conocido el panorama general de estos últimos en nuestro Derecho. Existen más de cien procedimientos contenciosos-administrativos para el conocimiento de la impugnación de los más variados actos, pero esta regulación especializada no ha llevado a definir la forma en que los jueces deben revisar la actividad administrativa sancionatoria ( $y$, en especial, el expediente construido por la Administración), ni tampoco las competencias del juez: si ellas se agotan con la pura anulación del acto (con el subsecuente reenvío del expediente al órgano administrativo) o si bajo ciertas condiciones, el juez puede dictar el acto sancionatorio de reemplazo².

El caso de la revisión judicial de las sanciones administrativas impuestas por la Superintendencia de Electricidad y Combustibles ("SEC") no escapa a estas preguntas. El actual sistema -instaurado por la Ley $N^{\circ} 18.410$, en 1999, gracias a las modificaciones introducidas por la Ley $N^{\circ} 19.613-$ encarga a las cortes de apelaciones el conocimiento del contencioso-administrativo. Pero lo hace sin responder las dos preguntas anteriores. En consecuencia, la Corte Suprema ha ido entregando algunas respuestas en los últimos años a través de un fenómeno que podría enmarcarse dentro de lo que la procesalística nacional ha denominado como una "jurisprudencia con poder normativo" 3 . En diversos fallos, la Corte se ha pronunciado sobre aspectos que abarcan, por ejemplo, la naturaleza del reclamo judicial (i.e. si alcanza solo a la legalidad o también se extiende al mérito de la decisión administrativa), la posibilidad de rendir prueba nueva en el contencioso, o los poderes del juez tras el acogimiento de la acción.

Este artículo busca ayudar a la debida comprensión de este contencioso-administrativo especial bajo un análisis de las distintas variables de diseño institucional que están en juego. La jurisprudencia de la Corte Suprema, como se verá, ha ido cristalizando durante los últimos años un modelo de contencioso-administrativo en base a una revisión cerrada, en que, por regla general, no es posible la discusión de los hechos ante el juez. Al mismo tiempo, la Corte ha señalado que la competencia revisora se agota en la

\footnotetext{
2 Sobre este tema y la cantidad de contenciosos, véase la Sección 1.2 más abajo y, en particular, nota al pie 33 .

3 La etiqueta es de Romero Rodriguez 2004, 128 y ss.
} 
legalidad, de modo tal que, si no hay un vicio de ilegalidad, no es posible modificar el acto impugnado. En este último caso, el juez podrá dictar una sanción de reemplazo solo en caso de que el vicio se haya producido en el acto sancionatorio, ya sea respecto de alguno de los elementos del acto (por ejemplo, debido a una errada calificación de la infracción o una falta de motivación) o bien, por infracción a los principios del Derecho Administrativo Sancionador (como el principio de proporcionalidad). Como contrapartida, frente a los vicios de procedimiento operará el reenvío del expediente a la Administración.

Aunque este sistema cuenta con una regulación legal poco profunda -en contraste con los modelos legislativos más recientes-, la construcción práctica que se ha ido gestando a su alero sí cuenta con ciertas ventajas o beneficios institucionales. La forma de la revisión judicial en sanciones eléctricas cuenta con una coherencia que permite optimizar las funciones de cada foro. En principio, el órgano administrativo quedará a cargo de la construcción de los hechos, mientras que la corte contará con competencias amplias para revisar la calificación de los hechos y las cuestiones de derecho planteadas por el particular (i.e. reclamante). En caso de una sentencia favorable, operará por regla general en reenvío del expediente a la SEC, salvo aquellas ilegalidades que se verifiquen en el acto sancionatorio, caso en el cual las cortes podrán modificar y recalificar la sanción impuesta. Este modelo, con sus desventajas -que, como se verá, sí las tiene- es más coherente y eficiente que otros modelos recientemente creados, como el de los tribunales ambientales.

Para ello, la estructura que asume este trabajo es la siguiente. En la Sección I se expondrá un marco que permita analizar adecuadamente el diseño institucional de revisión judicial de sanciones administrativas, pasando (I.1) desde la clásica distinción entre recurso de anulación (por exceso de poder) y recurso de plena jurisdicción, a (I.2) un modelo más completo en base a las variables de diseño institucional que hay envueltas en el derecho administrativo sancionatorio y en su posterior revisión judicial. Estas variables incluyen el foro encargado de la imposición de sanciones (i.e. la Administración o los tribunales de justicia), la naturaleza del subsecuente contencioso-administrativo, la especialización del tribunal, sus competencias, entre otras. Esto permitirá entregar un marco analítico que permitirá comprender de manera más adecuada el sistema de revisión judicial eléctrica actual.

Con estas variables institucionales en mente, en la Sección II se expondrá el sistema que se ha ido consagrando en la revisión judicial de las sanciones eléctricas impuestas por la SEC. Para ello, (II.1) se pondrá especial atención en la forma en que la Corte Suprema ha entendido en el último tiempo las normas de la Ley $N^{\circ} 18.410$. En las sentencias dictadas en los últimos meses, (II.2) la Corte Suprema ha consolidado la idea de lo que en Derecho Administrativo se conoce como un modelo de "revisión cerrada": el tribunal, en principio, solo revisa los antecedentes del expediente administrativo y sin reconstruir todos los hechos que han motivado la dictación del acto administra- 
tivo sancionatorio. Al mismo tiempo, la Corte ha entendido que los tribunales pueden dictar el acto sancionatorio de reemplazo solo cuando la ilegalidad se ha verificado en el acto terminal del procedimiento administrativo.

En la Sección III se comentarán y analizarán (III.1) las ventajas y desventajas institucionales de este modelo de revisión cerrada que ha sido creado jurisprudencialmente, y (III.2) se comparará con un modelo más actual: el instaurado por la Ley $\mathrm{N}^{\circ} 20.600$, que creó los tribunales ambientales. Con ello se demostrará que el modelo de revisión judicial de sanciones eléctricas, con su regulación escueta, a cargo de las cortes de apelaciones -tribunales generalistas, y no especializados- es más coherente y aprovecha de menor manera las características y atribuciones de cada foro (administrativo y judicial), en contraste al sistema creado por la Ley $N^{\circ} 20.600$. Esto, en último término, debería ser tomado una luz de alerta entre nosotros, para pensar cuidadosamente la idea de que la pura creación de tribunales administrativos especiales -sin razonar debidamente sobre su diseño institucional ni sobre el procedimiento judicial en sí mismo- constituye la solución pura al contencioso-administrativo nacional.

\section{Modelos de revisión judicial en las sanciones administrativas}

\section{Cinco variables en el diseño institucional de sanciones}

Una revisión de la literatura chilena tradicional en la materia nos lleva a identificar dos grandes modelos que buscan explicar la forma en que el juez escruta la labor administrativa, siguiendo en esto la teorización que en el Derecho francés se había levantado en base al funcionamiento del Consejo de Estado 4 . Se ha hablado, así, de "contencioso de plena jurisdicción" y de "contencioso de anulación" ${ }^{5}$. En apretada síntesis, ambos pueden conceptualizarse en que, por una parte, bajo el modelo de contencioso de plena jurisdicción el juez tiene amplias potestades para conocer de los hechos y del derecho, de modo que cuenta con competencia no solo para anular y sustituir la decisión de la Administración, sino también para condenar eventualmente a esta. Por la otra, el modelo de contencioso de anulación o por exceso de poder busca la nulidad de un acto administrativo dictado en contravención a la legalidad y, por lo mismo, las atribuciones del juez son más limitadas, ya que aquí solo se pronuncia sobre la legalidad o ilegalidad de la decisión y su consecuente anulación. En el Derecho francés, el correlato de esta diferencia de modelos se encuentra en los requisitos de legitimación activa al ejercer cada acción: mientras en el contencioso de plena jurisdicción era necesaria la invocación de una situación subjetiva vulnerada, el recurso de anulación no descansa sobre este requisito, y la identificación de un interés en el recurso pasaba a ser solo un

\footnotetext{
${ }^{4}$ Cfr., al respecto, Ferrada Bórouez 2016 con numerosas citas. A modo meramente ejemplar, SILVA CIMMA 1994, 189.

5 Sobre las características principales de cada modelo en Francia, y su consecuente recepción en el medio chileno, Ferrada Bórouez 2016, 322 y ss.
} 
requisito de seriedad del ejercicio de la acción, pero que no tiene trascendencia mayor en la resolución del fondo del asunto ${ }^{6}$.

El binomio contencioso-administrativo de anulación/de plena jurisdicción ha sufrido diversos ataques académicos a lo largo de las últimas décadas que exceden, desde luego, al objetivo de estas líneas ${ }^{7}$. Sí me parece que, para efectos de este trabajo, esta clasificación no permite capturar todos los tonalidades necesarias para pintar un retrato comprehensivo de todas las diferencias y matices que exhiben, hoy en día, nuestros contenciosos administrativos relacionados con la imposición de sanciones a particulares. Por lo pronto, el tema de la legitimación es particularmente distinto en nuestro país, requiriéndose por regla general una afectación subjetiva como requisito para accionar contra la Administración ${ }^{8}$. Además, esta clasificación tampoco permite explicar el desarrollo de los contencioso-administrativos en Chile, en donde las competencias del tribunal en el evento de una sentencia favorable tampoco guardan congruencia con el modelo de revisión limitada sobre el expediente administrativo que es planteado en cada caso ${ }^{9}$. Una mirada en detalle al panorama de contenciosos chilenos hace necesaria la consideración de cinco variables que permiten describir adecuadamente el diseño institucional de imposición y revisión de sanciones administrativas ${ }^{10}$.

Una primera variable está dada por el modelo de imposición de sanciones. Así, la Administración puede ejercer su potestad sancionatoria en base a un modelo inquisitivo, en donde el organismo administrativo cuenta con potestades para imponer una sanción tras la tramitación de un procedimiento administrativo. En estos casos, la misma Administración estará encargada de

\footnotetext{
${ }^{6}$ La expresión más extendida se encuentra expuesta en Duguit 2007 [1913], 100. Más recientemente, cfr. García de Entería Martínez-Carande 2007, 49.

7 Por ejemplo, Duguit 2007 [1913] (criticando que esta teoría "no entrañaba más que incertidumbre y contradicción" y prefiriendo, en cambio, la distinción de "contencioso objetivo" y "contencioso subjetivo"). También pareciera ser la postura de García de Enterría Martínez-Carande 2007, 80 y ss. (quien plantea que tras las leyes francesas de 1980 y 1995 el recurso contencioso-administrativo es "una verdadera y plenaria acción procesal de condena de la Administración").

8 P. ej., FerRada Bórouez 2012, 124 (apuntando que "Los sistemas de justicia administrativa han evolucionado paulatinamente hacia modelos subjetivos, especialmente a partir del reconocimiento del derecho fundamental a la acción o a la tutela judicial. El sistema de justicia administrativa chileno también ha tenido esta misma evolución, lo que se ha consolidado con la entrada en vigencia de la Constitución de 1980 y el reconocimiento expreso de la "lesión de derechos" como elemento central de su configuración institucional. Los procesos administrativos en nuestro derecho se han alineado en general con este proceso constitucional, considerando la tutela de posiciones jurídicas subjetivas, como fundamento y finalidad de la protección jurisdiccional. Así, a partir de diversas denominaciones, ha reconocido legitimación activa para incoar estos procesos a los interesados, agraviados o afectados, estableciendo una conexión con los intereses, como categoría conceptual básica").

9 Sobre este punto, ver Sección 2 siguiente. Como se explica allí, en materia eléctrica se ha tendido hacia un modelo de revisión cerrada (similar al previsto para el contencioso de anulación), pero en que ello no le impide al juez igualmente dictar, en ciertos casos, un acto sancionatorio de reemplazo.

10 En esto sigo en gran parte el estudio que, tomando como base distintos sistemas a nivel comparado (en civil y en common law), hace Asımow 2016.
} 
imponer la sanción previa tramitación de un procedimiento administrativo (generalmente, en aplicación de las normas de la Ley $N^{\circ} 19.880$ como legislación supletoria). Tal ocurre, por ejemplo, con la autoridad sanitaria, el Servicio Nacional de Geología y Minería, la Dirección del Trabajo o la Superintendencia del Medio Ambiente. En contrate, un modelo acusatorio obliga a la Administración a llevar su caso ante los tribunales para que sean estos quienes apliquen la sanción contra el infractor. Es lo que ocurre, por ejemplo, en materia de libre competencia, protección del consumidor o aguas. En estas áreas, la Fiscalía Nacional Económica, el Servicio Nacional del Consumidor (al menos en los procesos colectivos) y la Dirección General de Aguas, respectivamente, deben iniciar un proceso judicial para que sea la jurisdicción quien, en definitiva, determine la aplicación de una sanción contra el particular.

En segundo término, estos modelos conllevan dos sistemas distintos de contencioso-administrativo como correlato a cada uno de ellos. Como es natural, la imposición de sanciones administrativas ad intra importa consecuencias jurisdiccionales distintas que aquellos casos en que la sanción es impuesta por los propios tribunales de justicia tras la tramitación de un juicio. De esta forma, modelos inquisitivos se traducen en un posterior contencioso-administrativo de nulidad, en que la jurisdicción se levanta como una instancia de revisión de lo que se ha obrado, en forma previa, ante la Administración ${ }^{11}$. Por el contrario, los modelos acusatorios por obligación se traducen en un contencioso-administrativo represivo, en que el juez impondrá la sanción administrativa tras la tramitación de un juicio con todas las etapas procesales necesarias ${ }^{12}$, incluyendo, desde luego, la recepción de prueba por parte de la Administración que busque acreditar la efectividad de la infracción ${ }^{13}$.

La adopción legislativa de uno u otro sistema de imposición de sanciones no es algo que esté guiado por criterios claros en nuestro medio. Podría pensarse que los modelos acusatorios responden a modelos históricamente más tradicionales y que la tendencia actual ha ido de la mano por transformar

\footnotetext{
11 Cordero Vega 2016, 618 (definiéndolos como el contencioso que tiene "por propósito que el juez señale la ilegalidad de un acto administrativo y, en consecuencia, declare la nulidad del acto respectivo"); BERMúdez SOTo 2011, 429-430 (señalando que este contencioso "protege a los administrados contra las arbitrariedades de la Administración y, además, sirve de medio de control de la legalidad de la actividad administrativa").

12 Sigo en esta definición a CoRDERO VEGA 2016, 620 (definiendo al contencioso represivo como aquel que tiene "por objeto que el juez aplique medidas de gravámenes concretas a un particular, como puede ser en los casos en que la sanción debe ser aplicada por el juez y no por la Administración. [...] En ellas la Administración carece de potestad sancionatoria directa, por lo cual se requiere recurrir a un tribunal para la aplicación de la misma"). En igual sentido, BERMÚdez SOTO 2011, 434 (aunque plantea, extrañamente, que en Chile no existirían contenciosos represivos).

13 Alguien podrá, desde luego, resistirse a la calificación de "sanción administrativa" a una sanción impuesta por un tribunal. Históricamente, de hecho, el Tribunal Constitucional chileno ha declarado que las sanciones administrativas son solo aquellas impuestas por la Administración del Estado. Cfr, por ejemplo Sentencia TC Rol N².264-2012 (2013) (señalando que "la sanción administrativa es un acto administrativo que se dicta después de un procedimiento administrativo, a consecuencia de una infracción de bienes jurídicos de naturaleza administrativa").
} 
modelos acusatorios en inquisitivos ${ }^{14}$. Los casos de los proyectos de ley introduciendo modificaciones a los regímenes de la Dirección General de Aguas y del Servicio Nacional del Consumidor, y que fueron anulados por el Tribunal Constitucional, son buenos ejemplos de ello. Cualquiera sea el caso, lo cierto es que la entrega de competencias sancionatorias a órganos administrativos conlleva casi de manera automática una especial preocupación por la existencia de un tribunal que esté a cargo de revisar dichas decisiones ${ }^{15}$, como una manifestación del derecho a la tutela judicial efectiva ${ }^{16}$. Sin ir más lejos, la reforma legislativa de 1999 que instauró el actual modelo contencioso administrativo en materia eléctrica encontró su origen en una inquietud similar ${ }^{17}$.

Una tercera variable, pero que no guarda relación con el modelo sancionatorio concreto que se adopte, está dada por la especialización del tribunal. De un lado, el contencioso-administrativo puede quedar a cargo de la jurisdicción ordinaria -o lo que la literatura denomina como "tribunal generalista"- ${ }^{18}$, que podrá ser a nivel de tribunal de primera instancia o en la jerarquía de las cortes de apelaciones ${ }^{19}$. Por el otro, también existe el caso de modelos que descansan sobre la instauración de tribunales especializados, como ha ocurrido recientemente con la jurisdicción tributaria y aduanera o los tribuna-

\footnotetext{
14 Aunque excede el presente trabajo, hay quienes han considerado que los modelos acusatorios -donde es el tribunal quien imponía la sanción- han tendido a responder a modelos más tradicionales, anteriores incluso a la tendencia exhibida a partir de la década de 1980 y que, como contrapartida, conllevo a entregarle generalizadamente a los órganos administrativos la atribución de imponer sanciones. En principio, podría decirse que hoy en día la entrega de facultades represivas a los tribunales de justicia ha sido una decisión de política pública inspirada por una desconfianza hacia la Administración traducida en la idea de que imponer sanciones es equivalente a juzgar (por ejemplo, Aróstica Maldonado 1989, Aróstica Maldonado 1991, Soto KLoss 2005). Bajo esta óptica, es interesante el caso del modelo de libre competencia instaurado en el 2003, con la Ley № 19.911. Esta ley creó el Tribunal de Defensa de Libre Competencia, pero en razón de un modelo inspirado en la reasignación de funciones entre la existente Fiscalía Nacional Económica (como el órgano acusador) y las entonces existentes comisiones preventivas regionales, preventiva central y resolutivas (BERNEDO SOTO 2013, 162-163).

15 Un ejemplo sintomático se encuentra, al respecto, en la historia de la creación de la Superintendencia del Medio Ambiente. El proyecto de ley en cuestión sufrió diversas complicaciones en su tramitación legislativa, a causa de la preocupación por sobre los poderes de fiscalización y sanción exorbitantes que tendría este organismo, de modo tal que era trascendental, para el adecuado funcionamiento de la futura institucionalidad ambiental, contar con un tribunal especializado. Al respecto, Méndez OrTiz 2017, 43 y ss.

16 Ferrada Bórouez 2014, 244 (sosteniendo que hoy en día, "...ya no es tan relevante quién es el detentador de la potestad sancionadora (problema de la doctrina clásica), sino que el ejercicio de esta tenga garantizada una instancia judicial revisora").

17 El mensaje que derivó finalmente en la Ley № 19.613, de 1999 daba cuenta de la creación de este reclamo de ilegalidad de competencia de las Cortes al mismo tiempo que se perfeccionaban las facultades fiscalizadoras y sancionatorias de la SEC. En la Comisión de Minería y Energía, en el Primer Trámite Constitucional, se dejó constancia que "este recurso [judicial] se justifica debido a la necesidad de establecer un contrapeso a las facultades que le otorgan al organismo fiscalizador" (Historia de la Ley No 19.613, 21).

18 Tapia Canales/Cordero Vega 2015.

19 En el medio chileno, la literatura ha señalado que es un rasgo característico la entrega del contencioso-administrativo a las cortes de apelaciones por sobre los tribunales de primera instancia (Carmona Santander 2005, 213; Santibañez Yañez 2016, 149).
} 
les ambientales. Nuevamente, en esta variable no existen directrices claras en relación al carácter del contencioso administrativo, como quiera que existen tribunales especializados tanto en modelos acusatorios (como ocurre, por ejemplo, con el Tribunal de Defensa de la Libre Competencia) ${ }^{20}$ como en modelos inquisitivos (que es el caso, por ejemplo, de los tribunales ambientales, que solo revisarán la sanción impuesta por la Administración) ${ }^{21}$.

En cuarto y quinto lugar, hay dos variables relevantes en relación a los contenciosos de nulidad, y que serán especialmente relevantes para el análisis de este trabajo. Una cuarta variable dice relación con grado de prueba que es admisible en el contencioso de nulidad y, en particular, que define la forma en que el juez revisor se enfrenta a la construcción de los hechos que ya consta en el expediente administrativo en base al cual se ha impuesto la sanción. La quinta variable, finalmente, radica en las facultades que tendrá el tribunal al acoger la acción contencioso-administrativa. Con todo, ambas variables requieren de una explicación detallada por separado.

2. Dos modelos de revisión judicial y de competencias frente al acto anulado

Cualquiera sea el foro en el que se lleve a cabo el contencioso-administrativo (i.e. tribunales generalistas o especializados, de primera o de segunda instancia), hay dos definiciones de diseño institucional relevante en el caso de los contenciosos de nulidad. La primera definición -o cuarta variable- está asociada a la extensión de la revisión judicial a la construcción de los hechos que ha hecho previamente la Administración. Esto lleva a hablar de modelos de "revisión cerrada" y "revisión abierta", según sea la forma en que el juez se enfrente al expediente administrativo durante el contencioso-administrativo $^{22}$. En los primeros, el juez solo revisa el expediente administrativo y la prueba que ya fue previamente rendida ante la Administración, sin poder admitir prueba nueva. Dicho de manera gráfica, el contencioso-administrativo opera como una especie de "apelación" frente a la construcción de los hechos que ha realizado el organismo administrativo. En los segundos, el reclamo judicial permite la introducción de prueba, alegaciones y razonamientos adicionales a los que pudieron haber sido propuestos en la sede administrativa previa ${ }^{23}$.

20 D.L. N ${ }^{\circ} 211$, arts. 18 y 26.

21 Ley $\mathrm{N}^{\circ} 20.600$, art. 30.

22 Asimow/Dotan, 2016. En Chile, Larrocau Torres 2019 los llama respectivamente tesis "minimalista" y "maximalista" de la revisión judicial.

${ }^{23}$ Los modelos de revisión cerrada tienden a generar, como es esperable, una mayor deferencia de parte de los tribunales a la construcción de los hechos que ha hecho previamente el órgano administrativo. El caso de los Estados Unidos es ejemplificatorio: en los primeros años del Siglo XX los jueces comprendieron que la intervención judicial no era necesaria -al menos, no para conducir una revisión "de nodo" o "abierta"- si el órgano administrativo cumplía con ciertos estándares de debido proceso y de independencia en su actividad, evitando así el abuso de sus potestades (ERNST 2014, 28-36). 
La segunda definición -o quinta variable- pasa por las competencias con que cuenta el tribunal revisor en caso de una sentencia favorable al particular. ¿Las competencias se agotan con la sola anulación del acto debiendo siempre reenviar el expediente al órgano administrativo o, por el contrario, hay casos en que pueden dictar algún acto de reemplazo o imponer órdenes al órgano?

En general, a nivel comparado los contenciosos de nulidad han tendido a ser de revisión cerrada. Hay dos ejemplos que pueden ser interesantes para efectos de este trabajo. En primer lugar, el caso de España es interesante tomando en consideración que la legislación administrativa chilena se ha nutrido históricamente de estas latitudes. En el sistema español, la jurisdicción contencioso-administrativa desempeñó históricamente un papel de "segunda instancia", en que solo podía conocer de las pretensiones y hechos planteados en el recurso administrativo, a través de la figura del "ministro-juez" ${ }^{24}$. La práctica de prueba en el juicio de revisión se encontraba limitada a la revisión del expediente que la Administración había construido en forma previa. Como consecuencia, el juez revisor carecía de competencias que fuesen más allá de la simple anulación del acto impugnado ${ }^{25}$. Este modelo cambió con la Ley de lo Contencioso Administrativo de 1959, en que se pasó a un modelo abierto de revisión judicial ${ }^{26}$.

En segundo caso, la situación de Estados Unidos es similar a la anterior. El modelo de revisión cerrada fue instaurado tempranamente por la Corte Suprema federal en 1910, a propósito de la impugnación de la fijación de precios decretada por la Comisión Interestatal de Comercio (Interstate Commerce Commission o "ICC") ${ }^{27}$. En aquel entonces, la Corte sostuvo que los tribunales deben decidir las cuestiones de derecho, pero guardando deferencia a las cuestiones de hecho y de política pública decididas por los organismos administrativos ${ }^{28}$. Años más tarde, la Corte también establecería formalmente lo que se denominó como la "record rule" (o "regla del expediente"): por regla general, la prueba nueva estaría prohibida en la revisión judicial ${ }^{29}$. Esta idea luego sería positivada legalmente con la dictación de la Ley de Procedimiento Administrativo de 194930, tras lo cual, la Corte Suprema confirmaría la idea de que los tribunales deben sujetarse, por regla general, al expediente administrativo que fue construido por la Administración y no pue-

\footnotetext{
24 Garcia de Enterria Martinez-Carande 2017, 620.

25 Esteve Pardo 2017, 258; Garcia de Enterría Martínez-Carande 2017, 621.

26 Esteve PARDo 2017, 258-259.

27 MerRILL 2011, 953; Asimow 2015, 11-13. Aunque antes de esto, los tribunales tenían a revisar "de novo" los hechos asentados por la Administración (ERNST 2014, 4 y ss.).

${ }_{28}$ ICC v. Illinois Central Railroad Co. (1910), 470-471.

29 Tagg Bros. v. United States (1930), 444-445. Esta doctrina sería luego continuada en Nat. Broadcasting Co. v. United States (1943).

30 Administrative Procedure Act (1946), sección 10(e)(5) (estableciendo que el tribunal deberá anular el acto administrativo y las conclusiones arribadas por la Administración, en caso de que no estén apoyadas "por evidencia sustancial").
} 
den dictar un acto de reemplazo, estando obligados a reenviar el expediente al órgano, en caso de acoger la impugnación ${ }^{31}$.

El caso de Chile es peculiar. Como es ampliamente sabido, el contencioso administrativo fue una de las deudas históricas del Derecho Administrativo nacional. El diagnóstico de la literatura es muy bien sintetizado por Cordero Vega, quien plantea que:

Mientras en el siglo XX el resto de los sistemas legales evolucionó en los mecanismos de resolución de controversias de derecho administrativo $y$, en especial, la compatibilidad entre el sistema tradicional de contenciosos administrativos como control de legalidad y acciones de tutela de derechos fundamentales después de la década de los 50, Chile siguió discutiendo sobre cuál era el modelo de contencioso administrativo que debía aplicarse en nuestro sistema, cuestión que incluso siguió bajo la Constitución de 1980 hasta la reforma de 1989, que dejó la regla de competencia general a los tribunales ordinarios ${ }^{32}$.

Esta anomia regulatoria derivó en un verdadero desorden del panorama del contencioso administrativo del que nuestra literatura ha dado debida cuenta. Es un hecho público que existen diversas acciones y procedimientos para la impugnación de actos administrativos en el derecho chileno, los que sobrepasan hoy la centena ${ }^{33}$. En cada caso, el Congreso ha ido fijando reglas distintas de tramitación consagradas para el caso puntual, con una tendencia a seguir como modelo la tramitación del recurso de protección ${ }^{34}$. Lo mismo ocurre con los tribunales competentes, los que pueden corresponder al juez civil, cortes de apelaciones, Corte Suprema o tribunales especiales, con una preferencia manifiesta por entregar el conocimiento de los reclamos a nuestras cortes de segunda instancia ${ }^{35}$.

La instauración especializada de acciones y procedimientos contencioso-administrativos no ha derivado, por desgracia, en una regulación acuciosa de los trámites procesales ${ }^{36}$. En muchos casos no existen trámites reglados, ni mucho menos un sistema probatorio unitario ${ }^{37}$. En general, cada contencioso administrativo es una evidencia de la opción por la evasión que ha adoptado históricamente el Congreso a la regulación de la prueba y a las competencias

\footnotetext{
31 United States v. Carlo Bianchi \& Co. (1963), 710-718 (confirmando el uso de la "record rule" de manera estricta). Flo. Power \& Light v. Lorion (1985) (señalando que, por regla general, los tribunales no pueden conducir revisiones "de novo" y el expediente debe ser devuelto al órgano administrativo en caso de acoger la impugnación).

32 Cordero Vega 2020, 23.

33 Carmona Santander 2005, 204 (quien, al 2003, contaba en 120 los procedimientos); y FerRAdA BÓRQUEz 2011, 264 (quien calculaba en sobre 140 los procedimientos contenciosos especiales en ese entonces).

34 Carmona Santander 2005, 218; Ferrada Bórouez 2011, 266.

35 Carmona Santander 2005; Ferrada Bórouez 2014; Santibáñez Yã̃ez 2016, 149.

36 Carmona Santander 2005, 220.

37 Romero Rodríguez 2020, 452.
} 
revisoras que tiene el juez contencioso-administrativo ${ }^{38}$. Por lo mismo, una gran pregunta en nuestro medio pasa, precisamente, por determinar la forma en que operan estas dos variables: (a) la forma en que el juez debe revisar el expediente administrativo y si puede o no recibir antecedentes adicionales a los planteados ante la Administración, y; (b) hasta dónde llegan las competencias revisoras: si ellas se agotan con la pura anulación del acto (operando un consecuente reenvío del expediente al órgano que lo dictó) o si en ciertas condiciones el juez puede dictar el acto sancionatorio en reemplazo de la Administración.

La abstinencia congresista en la materia ha llevado que sea la jurisprudencia quien colme este silencio ${ }^{39}$. En Chile, muchos contenciosos-administrativos están configurados como una apelación y el correlato de ello es que el reclamo judicial se transforma en "una mera revisión de lo obrado" ante el órgano administrativo ${ }^{40}$, lo que restringe a su vez los poderes del juez para admitir prueba nueva ${ }^{41}$. Pero la instauración de modelos "cerrados" de revisión judicial no ha impedido que las cortes puedan recalificar la sanción impuesta previamente por la Administración cuando detectan ilegalidades en su imposición. De esta forma, en nuestro país la forma de la revisión no incidiría en las competencias del juez, quien podrá modificar la sanción que ha sido fijada por el organismo reclamado. La revisión judicial de las sanciones eléctricas es un preclaro ejemplo de lo que se ha venido comentando.

\section{La revisión de sanciones eléctricas}

\section{El diseño institucional de la Ley $N^{0} 18.410$}

Tras los párrafos anteriores ya estamos en condiciones de analizar el esquema sancionatorio establecido en la Ley $N^{\circ} 18.410$. En esto no hay enigma alguno: la ley asume un modelo inquisitivo en el que la sanción es impuesta por un órgano administrativo -la Superintendencia de Electricidad y Com-

\footnotetext{
38 Valdivia Olivares 2017, 372-373 (señalando que es "paradójico, porque escamotea lo esencial, que estas reglas procesales rara vez se refieran a los poderes del juez").

39 Como ocurre en otras materias, como en la creación de sanciones procesales o en la delimitación de la legitimación activa. Cfr., Romero Rodríguez 2004, 128 y ss.

40 Reyes Poblete 2014, 340. Santibánez YÁñez 2016, 146, 148 (puntualizando que "se podría sostener que el legislador chileno ha sido reacio a incorporar y regular la prueba de manera sistemática en el contencioso administrativo atendido que nuestro modelo de referencia tradicionalmente le atributó un carácter revisor a esta jurisdicción, lo cual implicaría que la actividad de la Administración solo puede ser enjuiciada sobre la base de los propios antecedentes reunidos durante el procedimiento administrativo, del mismo modo que un tribunal de casación enjuicia una sentencia, todo ello como una forma se asegurar la deferencia técnica, afirmación que ha sido objeto de crítica").

41 Ferrada Bórouez 2014, 251 (planteando que, en muchos procedimientos judiciales de revisión de actos administrativos, "la actuación del órgano administrativo es mirada como una sentencia de un juez de primera instancia, correspondiendo al tribunal revisor actuar solo como una instancia de apelación" con una evidente "limitación intrínseca del juez para revisar los hechos sobre los cuales se construye la sanción administrativa").
} 
bustibles- ${ }^{42}$ con posterior posibilidad de impugnar tal decisión ante la Corte de Apelaciones respectiva -un juez generalista- a través de un contencioso de nulidad ${ }^{43}$. En el procedimiento de reclamación, la Corte confiere traslado de la reclamación a la SEC para que evacúe un informe en un plazo de diez días ${ }^{44}$, tras lo cual tendrá lugar la vista de la causa. La Corte "podrá, si lo estima pertinente, abrir un término probatorio que no podrá exceder de siete días en forma previo a los alegatos de las partes" 45 .

La claridad conceptual en estas primeras tres variables evidencia como contrapartida la falta de precisión en las dos restantes. Si, de acuerdo a las normas de la Ley $\mathrm{N}^{\circ} 18.410$, es notorio que: (a) el modelo sancionatorio es inquisitivo, quedando en manos de la SEC la imposición de la sanción, (b) con un posterior contencioso-administrativo de nulidad, (c) ante un tribunal ordinario (i.e. las cortes de apelaciones); no ocurre lo mismo con las facultades de revisión y las competencias que tienen dichos tribunales en el contencioso-administrativo. La ley, haciendo eco del panorama general en los contenciosos-administrativos nacionales, no establece en forma expresa el grado de prueba que es admisible ante las cortes, ni mucho menos qué competencias tienen estas al decretar la anulación del acto impugnado. El artículo 19 de la Ley $N^{\circ} 18.410$ solo señala que la corte respectiva dictará sentencia en un plazo de quince días ${ }^{46}$, pero sin referirse acerca del contenido de la misma o de las posibilidades que tiene la corte para dictar un acto de reemplazo.

\section{Las competencias revisoras según la jurisprudencia}

Los vacíos anteriores han sido solucionados por la jurisprudencia más reciente de la Corte Suprema sobre el reclamo de ilegalidad de la Ley Nº 18.410 en materia de sanciones eléctricas. Hay dos líneas jurisprudenciales que se han ido elaborando en la materia durante los últimos años.

Por una parte, la jurisprudencia de la Corte Suprema ha ido cristalizando un modelo de contencioso-administrativo en base a una revisión cerrada, y que se manifiesta en cuatro criterios. Primero, el reclamo de ilegalidad de la Ley $N^{\circ} 18.410$ es de derecho estricto, sin que el juez pueda variar la fijación de los hechos que ya fue construida por la Administración. Segundo, como consecuencia de lo anterior, la apertura de un probatorio en el contencioso-administrativo -prevista en el artículo 19- es "una facultad del tribunal revisor". Esto genera dos consecuencias en la sede administrativa: Tercero, que es la SEC quien tiene que soportar la carga de la prueba (i.e. la ocurrencia de los hechos que configuran la infracción), y cuarto, que en el procedimiento

\footnotetext{
42 Ley $\mathrm{N}^{\circ}$ 18.410, art. 7(g), art. $15 \mathrm{y}$ art. 17.

43 lbid., art. 19, inc. 1 y 2.

44 Ibid., art. 19, inc. 3.

45 Ibíd., art. 19, inc. 5. Este punto también ha sido relevado por la misma literatura nacional, cfr. Carmona Santander 2005, 221; Ferrada Bórouez 2014, 252; Romero Rodríguez 2020, 453.

46 Ley $N^{\circ} 18.410$, art. 19, inc. final.
} 
administrativo -a diferencia del contencioso- la apertura del probatorio es una obligación, y no una mera facultad con que cuente la SEC.

En primer lugar, la Corte ha señalado que, en el marco de la Ley $N^{\circ} 18.410$, el reclamo de ilegalidad es de derecho estricto, sin que en el contencioso-administrativo se puedan variar los presupuestos de hecho ya determinados por la SEC en el expediente administrativo sancionatorio. La Corte ha resuelto de manera consistente, en un considerando que a estas alturas es paradigmático:

Que, como surge de lo expuesto, el reclamo de ilegalidad en análisis constituye un mecanismo de revisión de la actividad administrativa sancionadora sectorial eléctrica, que tiene como principal característica ser de derecho estricto, es decir, su finalidad se restringe a la revisión de la juridicidad, tanto adjetiva como sustantiva, del actuar de la Superintendencia de Electricidad y Combustibles, sin que sea posible por esta vía variar los presupuestos fácticos que fueron determinados en sede administrativa ${ }^{47}$.

El problema que plantea, en principio, esta postura, es que ella genera el problema de dejar en inutilidad la facultad que tiene el tribunal revisor de abrir un término probatorio. La literatura nacional ha mirado el artículo 19 de la Ley $N^{\circ} 18.410$ como un caso ejemplar en que se ha permitido la rendición de prueba ${ }^{48}$, y que ello permitirá controvertir la fijación de los hechos que ha realizado la SEC en la sede administrativa al imponer la sanción ${ }^{49}$. Alejándose de esta idea, en segundo lugar, la Corte Suprema ha señalado que en la reclamación judicial eléctrica la apertura de un probatorio es una facultad del tribunal revisor:

Que lo mismo es aplicable al aspecto judicial y, con mayor razón, desde que el artículo 19 de la Ley N 18.410, señala que: 'Evacuado el traslado por la Superintendencia, vencido el plazo de que dispone para formular observaciones, el tribunal ordenará traer los autos en relación y la causa se agregará extraordinariamente a la tabla de la audiencia más próxima, previo sorteo de la Sala. La Corte podrá, si lo estima pertinente, abrir un término probatorio que no podrá exceder de siete días, y escuchar los alegatos de las partes [...].

\footnotetext{
47 Naser con SEC (2020), c. 5. En idéntico sentido, p. ej., Enel Distribución con SEC (2020); Metrogas S.A. con SEC (2020); Dimarsa Ltda. con SEC (2019); Inmobiliaria Los Coihues con SEC (2019); Arcos y Cía Ltda. con SEC (2019); Enel Distribución con SEC (2019); Miguelez con SEC (2019).

48 A modo meramente ejemplar, Carmona Santander 2005, 220-221 (dando cuenta que la mayoría de los contenciosos carece de trámites reglados, con excepciones que consagran un trámite de audiencia o la posibilidad de rendir prueba).

49 Ferrada Bórouez 2014, 252 (señalando que el caso de la Ley $N^{\circ} 18.410$ es un ejemplo de aquellos procedimientos "en que se consideran ciertas reglas destinadas a la revisión de los hechos [...] en cuanto consideran la facultad al juez para abrir un término probatorio en el que las partes podrán aportar las pruebas que controviertan lo establecido por la Administración en la fase administrativa").
} 
En este contexto, queda en evidencia que la apertura de un término probatorio en este proceso, corresponde a una facultad del tribunal, desde que sus fines son determinar que la decisión adoptada por la Administración se ajustó a derecho y no revisar los presupuestos fácticos asentados por la Administración, salvo que estos hayan sido establecidos en contravención a la ley, lo cual conforme se advierte del mérito de los antecedentes, no aconteció en la especie ${ }^{50}$.

Explicado en términos gráficos, pareciera que para la Corte la reclamación judicial eléctrica se encuentra más cercana a una casación que a una apelación. No debe llamar la atención el hecho que pueda abrirse un término probatorio pues bajo las reglas del Código de Procedimiento Civil, en la casación es posible abrir un término probatorio excepcional si "la causal alegada necesita probarse" (art. 794 CPC). Esto es similar al entendimiento que tiene la corte en cuanto a que el probatorio en la reclamación judicial eléctrica está enfocado a "determinar que la decisión adoptada por la Administración se ajustó a derecho".

La comprensión que ha construido la Corte Suprema en los últimos años se ha manifestado, como correlato, en una visión del procedimiento sancionatorio como la sede por excelencia en que deberán ser probados los hechos. Esto lleva nuevamente a dos criterios jurisprudenciales. En tercer lugar, se ha establecido que la SEC tiene el peso de demostrar la ocurrencia de los hechos que configuran la infracción respectiva, "debiendo agotar los medios disponibles para verificar si dicha transgresión fue, efectivamente cometida, de qué modo ocurrió y quién es el responsable de su realización":

En efecto, atendida la naturaleza, características y fines propios del Derecho Administrativo Sancionador, recae sobre la autoridad que investiga y acusa, esto es, sobre el órgano fiscalizador, el peso de demostrar la ocurrencia de los hechos que configuran la infracción respectiva [...].

De tales predicamentos se desprende, como es evidente, un mandato que los engloba y que obliga a la Administración a ejercer sus facultades y a cumplir sus deberes de manera que los mismos se vean plenamente satisfechos, de lo que se sigue, como es natural, que si reprocha a un particular la comisión de una determinada infracción deberá agotar los medios disponibles para verificar si dicha transgresión fue, efectivamente, cometida, de qué modo ocurrió y quién es el responsable de su realización ${ }^{51}$.

En cuarto lugar, como correlato de lo anterior, la Corte Suprema ha establecido que la apertura de un probatorio en la sede administrativa es una obligación de la SEC, y no una mera facultad, de modo tal que el órgano debe recibir la prueba ofrecida por el particular. Así, la Corte ha señalado que:

50 Metrogas S.A. con SEC (2020), c. 9.

51 Suárez con SEC (2019), c. 3. En el mismo sentido, Chilectra S.A. con SEC (2017). 
Que, de este modo, la prueba testimonial ofrecida por el administrado debió ser recibida por la Superintendencia reclamada, si se considera que el inciso $1^{\circ}$ del artículo 35 de la Ley $N^{\circ} 19.880$ [...] establece una verdadera garantía en favor del administrado, consistente en la posibilidad de cuestionar la efectividad o exactitud de los hechos propuestos por la Administración [...].

Que, así, el incumplimiento de esta obligación por la Superintendencia de Electricidad y Combustibles torna a esta parte de la decisión en ilegal, siendo dable precisar que, desde esta perspectiva, la recepción de la causa a prueba no constituye una potestad de la Administración, sino un imperativo legal ${ }^{52}$.

En síntesis, la Corte Suprema ha entendido bajo esta primera línea jurisprudencial, que es en sede administrativa donde deben quedar probados los hechos que sustentarán la imposición de la sanción por parte de la SEC, lo que conlleva que la carga de la prueba deba ser soportada por este organismo fiscalizador. El contencioso-administrativo en materia eléctrica, bajo la comprensión de la Corte Suprema, opera bajo una revisión cerrada, en que por regla general no se admitirá prueba nueva.

Por otra parte, una segunda línea jurisprudencial dice relación con las competencias que tienen los tribunales en el contencioso-administrativo, tras la anulación del acto sancionatorio dictado por la SEC. ¿Puede, la corte, reemplazar a la Administración, modificando la sanción impuesta en el sancionatorio? En esta materia, la Corte ha sostenido que la competencia revisora del juez se agota con la revisión de legalidad del acto sancionatorio, de modo que no alcanza el mérito de lo obrado por la SEC:

Que esta Corte ha establecido que la competencia que se le ha conferido a los tribunales conforme con lo dispuesto en el artículo 19 de la Ley $N^{\circ} 18.410$ se agota con la determinación de la legalidad o ilegalidad del acto administrativo que impone la sanción. Ergo, si los sentenciadores consideran que la resolución que impone la sanción es legal, carecen de atribuciones para rebajar la multa ${ }^{53}$.

En otras palabras, la Corte Suprema ha hecho eco en esta materia de lo planteado en otras sedes ${ }^{54}$, agregando que si no hay vicio de ilegalidad entonces es improcedente rebajar la multa:

[...] la competencia del tribunal viene dada por la naturaleza del recurso de reclamación, en tanto control de legalidad", de manera que, para modificar la resolución dictada por la autoridad reguladora competente,

\footnotetext{
52 Naser con SEC (2020), c. 11-12.

53 Transelec con SEC (2019), c. 7.

54 Ferrada Bórouez 2014, 259 (planteando que "los tribunales de justicia se han inclinado a menudo por afirmar su plena competencia para revisar la aplicación de la sanción administrativa, anularla o rebajarla, configurando ella como una potestad intensa de revisión judicial del acto administrativo $\left.[\ldots]^{\prime \prime}\right)$.
} 
es necesario "dar por establecida la ilegalidad, invalidar el acto administrativo y disponer la decisión adecuada al caso, si procediere, conforme a los límites de su competencia en un reclamo de ilegalidad ${ }^{55}$.

En términos similares, la Corte también ha sostenido:

Que, en las condiciones expuestas, es improcedente rebajar la multa, toda vez que la competencia de la Corte en esta materia, tal como lo expone la apelante, se vincula con la determinación de la legalidad o ilegalidad del acto administrativo que impone la sanción. Ergo, si los sentenciadores consideran que la resolución que impone la sanción es legal, carecen de atribuciones para rebajar la multa, siendo improcedente fundarse incluso en las alegaciones que dieron pábulo al reclamo de ilegalidad ${ }^{56}$.

Con todo, este criterio reconoce algunos matices pues no toda ilegalidad dará lugar a que se active la competencia que tienen las cortes para dictar una sanción de reemplazo. La línea divisora planteada por la Corte se encuentra en la clásica distinción de ilegalidades de procedimiento e ilegalidades incurridas en el acto terminal. En el primer caso, el juez reenviará el expediente a la Administración, quien deberá subsanar las ilegalidades detectadas en el contencioso-administrativo:

En efecto, la presencia de un vicio en el procedimiento administrativo respectivo debería desembocar, por regla general, en la anulación de lo obrado en esa sede, con el objeto de que, corrigiéndolo, se llevara adelante un nuevo proceso libre de semejante imperfección. Empero, en el caso en examen el defecto se verificó en el acto que puso término al procedimiento, de modo que este último se encuentra exento de deficiencias, consideración que demuestra lo innecesario de un proceder tan drástico como el descrito, pudiendo ser solucionada la falla descrita más arriba mediante la intervención directa de la jurisdicción ${ }^{57}$.

Por otra parte, si el vicio se genera en la dictación del acto, el juez podrá sustituir a la Administración, dictando la sanción aplicable. Así, el juez podrá dictar la sanción de reemplazo cuando el acto carece de una motivación adecuada:

Que, tal como lo señala correctamente la sentencia impugnada, la resolución que impuso la multa al infractor no expresó las circunstancias que llevaron a la reclamada a determinar el quantum de la sanción. La antedicha falta de fundamentación de la resolución reclamada, contra-

\footnotetext{
55 SEC con Enel Distribución Chile (2019), c. 3 (citando Chilquinta Energía con SEC (2017)).

56 Sistema de Transmisión del Sur S.A. con SEC (2019), c. 5. En igual sentido, por ejemplo, Transelec con SEC (2019), c. 7 (señalando que "la sentencia de alzada descarta la ilegalidad de la sanción, empero rebaja el quantum de la multa, cuestión que, como se señaló, es improcedente..."); SEC con Enel Distribución Chile (2019); Chilquinta Energía con SEC (2017); Luz Linares con SEC (2017); CGR Distribución S.A. con SEC (2016).

57 INGCER S.A. con SEC (2019), c. 5. En igual sentido, Chilectra S.A. con SEC (2017b), c. 14.
} 
viene lo dispuesto en el artículo 40 de la Ley $N^{\circ}$ 19.880. Sin embargo, tal ilegalidad en la actuación de la SEC carece de relevancia en el caso concreto, puesto que en el caso en examen el defecto se verificó en el acto que puso término al procedimiento, de modo que este último se encuentra exento de deficiencias, pudiendo ser solucionada la falla descrita mediante la intervención directa de la jurisdicción como razonó la Corte de Apelaciones ${ }^{58}$.

De igual forma, la corte también podrá dictar la sanción de reemplazo cuando haya detectado errores en la ponderación de los hechos por parte de la SEC:

Que, en consecuencia, resultaba deber del órgano jurisdiccional estudiar la eventual recalificación del castigo orientado por los factores objetivos establecidos en la ley, adoptando, en este aspecto, la posición que originalmente correspondía a la Administración. En esa labor, se estima adecuada la ponderación que realizó la Corte de Apelaciones al sustituir la multa por la amonestación por escrito, porque efectivamente concurrían a favor del administrado el que no hay usuarios afectados, ni beneficio económico obtenido por la reclamante, no existió intencionalidad en la comisión de la infracción imputada, además, de contar el reclamante con una conducta previa intachable y de haber reparado el mal causado; y, en particular, que los productos indicados en los cargos formulados cuentan con la correspondiente certificación, aun cuando no aparecen en las fotografías en la página web, para su comercialización, como lo reconoce la propia resolución sancionatoria ${ }^{59}$.

En síntesis, el marco legal de la Ley $N^{\circ} 18.410$ ha permitido a la Corte Suprema ir interpretando las reglas procesales y decantándolas, por una parte, en un marco de revisión cerrada. El reclamo será, entonces, de derecho estricto y la prueba nueva será excepcional. Por otra parte, la corte revisora podrá dictar el acto de reemplazo siempre que se trate de vicios que se hayan verificado en el acto terminal. De lo contrario, operará el reenvío del expediente a la SEC para que subsane las ilegalidades del caso.

\section{La coherencia del sistema de revisión}

Como se dijo en la sección anterior, el modelo de revisión judicial en materia de sanciones eléctricas ha sido concebido por la Corte Suprema como un

\footnotetext{
58 Sánchez y Sánchez con SEC (2020). En igual sentido, INGCER S.A. con SEC (2019) (señalando que "si bien la descrita falta de motivación otorga mérito para impugnar la resolución reclamada por la ilegalidad cometida, lo cierto es que de su constatación prosigue que esta Corte se encuentre en situación de, sustituyendo a la Administración, calificar los hechos materia de autos") y Arcos y Cía Ltda. con SEC (2019)(estableciendo que constatada la ilegalidad por ausencia de fundamentación en la determinación de la cuantía de la infracción, resultaba deber del órgano jurisdiccional estudiar la eventual reducción del castigo orientado por los factores objetivos establecidos en la ley, adoptando, en este aspecto, la posición que originalmente ostentaba la Administración").

59 Dimarsa Ltda. con SEC (2019).
} 
modelo de revisión cerrada. El reclamo judicial de la Ley $N^{\circ} 18.410$ ha sido comprendido como un reclamo de ilegalidad, de revisión cerrada, en el que el tribunal eventualmente, si lo estima necesario, puede abrir un término probatorio. Con este panorama en mente, el objetivo de esta sección es doble. Por una parte, se mostrará la coherencia del modelo de revisión creado jurisprudencialmente en base a la Ley $N^{\circ}$ 18.410: aunque tiene sus desventajas identificadas plenamente por la literatura nacional, el modelo creado jurisprudencialmente tiene una lógica interna que, en cierto modo, se amolda a las características institucionales de los órganos envueltos en las sanciones eléctricas. Por otra parte, se demostrará que dicha coherencia es más fuerte si se compara el modelo de la Ley $N^{\circ} 18.410$ con otros más novedosos, como el instaurado a propósito de los tribunales ambientales.

\section{La coherencia interna}

La revisión abierta es una de las grandes características en el contencioso-administrativo que la literatura nacional ha demandado a lo largo de los últimos años. Se ha planteado entre nosotros que el respeto al derecho a la tutela judicial efectiva -consagrado en el artículo $19 \mathrm{~N}^{\circ} 3$ de la Constitución Política- hace necesario el amplio control de los hechos por parte del juez contencioso-administrativo, que le permita revisar ampliamente la facticidad del expediente administrativo ${ }^{60}$. Hay quienes incluso han propuesto la posibilidad que sea el juez quien aporte pruebas al proceso ${ }^{61}$. Por lo mismo, se ha criticado aquellos casos de contenciosos configurados en base a procedimientos de apelación o del recurso de protección -i.e., modelos de revisión cerrada-, que restringen los poderes del juez para admitir prueba nueva y valorarla ${ }^{62}$. Bajo esta perspectiva, es preocupante que las cortes no hagan uso de la facultad de abrir un término probatorio en el contencioso-administrativo de revisión de sanciones eléctricas.

Este demérito del modelo cerrado tampoco debe hacernos caer en su demonización, pues hay dos ventajas comparativas con las que él cuenta. La primera ventaja - de carácter conceptual- es que este esquema permite una especialización de funciones entre órganos administrativos y tribunales de justicia, evitando la fricción institucional y la duplicación de esfuerzos ${ }^{63}$. Por una parte, los organismos administrativos se especializan en elaborar expedientes administrativos y fijar los hechos en la materia de su competencia. Por la otra, los tribunales -especialmente las cortes, en tanto tribunales gene-

\footnotetext{
60 Reyes Poblete 2014, 340; Ferrada Bórouez 2014, 247 y 254 (planteando que "para estar ante un efectivo control judicial de la potestad sancionadora de la Administración, y satisfacer el estándar jurídico que impone la vigencia del Estado de Derecho que señala la doctrina y la jurisprudencia comparada, este control debe ser pleno y completo. Esto implica la habilitación al juez para revisar los hechos y el derecho tenido en cuenta por la Administración para aplicar la sanción correspondiente".)

61 Bordali Salamanca 2005, 379.

62 Ferrada Bórouez 2014, 251-252.

63 Sobre esto, Merrill 2011, 1000.
} 
ralistas- se enfocan en revisar las conclusiones jurídicas con el fin de armonizar la acción administrativa en torno a las grandes instituciones del Derecho (entre ellas, la observancia de la tramitación administrativa y el respeto a las garantías fundamentales) ${ }^{64}$. De esta forma, el modelo de apelación, como el instaurado bajo las reglas de la Ley $N^{\circ} 18.410$, permite optimizar las funciones en cada foro.

Por lo mismo, pareciera que los modelos de revisión cerrada son los más adecuados cuando el Congreso ha encargado la revisión a una corte de apelaciones. En estos modelos, el tribunal no estará preocupado de generar un expediente con la fijación de los hechos, porque el mismo ya fue construido en forma previa por el órgano administrativo. En esta línea, las cortes de apelaciones son el foro más adecuado en esta clase de revisión porque ellas generalmente no reciben prueba, sino que su labor es más bien de revisión de lo construido en primera instancia ${ }^{65}$. En contraposición, la instauración de un modelo de revisión abierta hace necesaria la intervención de tribunales de primera instancia, quienes cuentan con características institucionales y una experiencia que facilitan la recepción y práctica de diligencias probatorias ${ }^{66}$.

Una segunda ventaja -ahora de carácter práctico- está dada por el hecho de que, si la corte pudiese introducir prueba nueva, el particular tendría un incentivo perverso de reservarse la mejor prueba para la etapa de revisión judicial y evitar así que ella sea anticipada por la Administración (una práctica que en el Derecho norteamericano se conoce como "sandbagging") ${ }^{67}$. Este incentivo sería especialmente alto en aquellos casos en que el contencioso no opera con el requisito del agotamiento previo de la vía administrativa, de modo tal que el particular podrá acudir a los tribunales tras el acto administrativo terminal. De esta forma, los modelos cerrados generan la carga o el deber en el particular de presentar todos los medios de prueba en sede administrativa, reservando para la posterior etapa judicial solo la discusión de cuestiones de derecho.

\footnotetext{
64 Tapia Canales/Cordero Vega 2015.

${ }^{65}$ CuRrie/Goodman 1975, 5. Por cierto, la distribución de la competencia revisora entre tribunales de primera instancia y cortes de apelaciones importa otro análisis de ventajas comparativas entre cada foro, que excede al presente trabajo.

66 Por lo señalado, aunque excede las líneas de este trabajo, es posible señalar a modo de conjetura que pareciera que los modelos de revisión amplia más adecuados -y que se condicen con tribunales de primera instancia- corresponden solo a modelos acusatorios: donde la Administración lleva el caso ante el juez, para que sea este, tras un contencioso represivo, quien imponga la sanción. Puesto en otras palabras, el riesgo de instaurar modelos inquisitivos con posterior revisión (i.e. contenciosos de nulidad) en tribunales de primera instancia conlleva el riesgo de duplicar trabajos y esfuerzos en ambos foros, y, en definitiva, de acentuar las fricciones institucionales entre ambos órganos.

67 Asimow/Dotan 2016, 525. Una explicación histórica en Ernst 2014, 36 y 37 (dando cuenta que, en Estados Unidos, la revisión judicial de los actos administrativos de la International Commerce Commission eran revisados bajo un modelo abierto, permitiéndose prueba nueva. La consecuencia que generó ello fue la ICC se transformase en un "órgano inútil, para todos los efectos prácticos", porque al final toda la prueba se terminaba rindiendo ante el tribunal. Ello cambió en 1906, con la Hepburn Act).
} 
De esta forma, el modelo contencioso-administrativo construido bajo las reglas de la Ley $N^{\circ} 18.410$ cuenta -con sus críticas y desventajas- con una coherencia interna que permite optimizar las funciones de cada foro. La construcción de los hechos quedará a cargo de la SEC, mientras que la corte revisora contará con competencias amplias para revisar la calificación de los hechos y las cuestiones de derecho planteadas por el particular (i.e. reclamante). Al mismo tiempo, las cortes solo dictarán un acto sancionatorio de reemplazo en caso de que la ilegalidad se haya detectado en el acto administrativo terminal; de lo contrario, corresponderá el reenvío del expediente a la SEC con la finalidad de que esta subsane las ilegalidades y dicte una nueva resolución sancionatoria.

\section{La coherencia frente a otros sistemas}

Volviendo ahora sobre el (desordenado) panorama general de los contenciosos-administrativos en nuestro país, es un aspecto conocido que las leyes especiales no cuenten con regulaciones acerca de los poderes que detenta el juez tras la sentencia favorable ¿Puede dictar una sentencia de reemplazo que modifique la sanción impuesta originalmente por la Administración? ¿O, por el contrario, sus facultades se limitan a la pura anulación del acto, estando obligado a reenviar el expediente a la Administración? Es paradójico que, mientras existe en el medio chileno una tendencia desesperada a regular contenciosos-administrativos prácticamente para cualquier tema, este sea un aspecto olvidado por el Congreso en la mayoría de los $\operatorname{casos}^{68}$.

Una excepción a este constante silencio se encuentra en la Ley $N^{\circ}$ 20.600. Solo recientemente, a propósito de la creación de los tribunales ambientales se ha regulado en detalle este tema ${ }^{69}$. Por lo mismo, puede resultar útil comparar la coherencia interna de la construcción jurisprudencial que se ha ido gestando al alero de las (escuetas) reglas de la Ley № 18.410, con este modelo institucional.

Los tribunales ambientales son tribunales contencioso-administrativos especializados, conformados por jueces especializados, que cuentan con competencias exclusivas y excluyentes en temas ambientales. El procedimiento de impugnación de actos ambientales es "sumarísimo" y, en pocas palabras, es virtualmente idéntico al del recurso de protección ${ }^{70}$. La prueba a rendir se encuentra limitada a la documental, de modo tal que la labor revisora del tribunal estará enfocada en el expediente que debe acompañar el organismo reclamado ${ }^{71}$. Por lo mismo, el contencioso ambiental opera bajo la

\footnotetext{
68 Supra sección 1.2.

69 Valdivia Olivares 2017, 372 y 373 (quien sostiene que: "Solo en el último tiempo se advierte una mayor preocupación en este campo, como lo muestra la novedosa regulación del dispositivo de las sentencias que se dicten los tribunales ambientales. Este ejemplo es significativo de que el oficio del juez de la administración requiere ser clarificado con más detalle, si se espera que se dé una respuesta satisfactoria a las peticiones del demandante").

70 Méndez Ortiz 2018.

71 Ibíd., 541.
} 
lógica de una revisión más bien cerrada ${ }^{72}$ y los hechos relevantes quedarán en su mayor parte probados en la sede administrativa.

Otra cosa distinta son las competencias con que cuenta el juez ambiental en caso de sentencia favorable. La Ley $N^{\circ} 20.600$ señala que la sentencia que acoja la acción "deberá declarar que el acto no es conforme a la normativa vigente $y$, en su caso, anulará total o parcialmente la disposición o acto recurrido y dispondrá que se modifique, cuando corresponda, la actuación impugnada"73. Aunque en base a esta norma se ha planteado que los tribunales ambientales cuentan con poderes amplios ${ }^{74}$, lo cierto es que, esta facultad encuentra sus límites, pues el tribunal no puede "determinar el contenido discrecional de los actos anulados" 75 . Como consecuencia de ello, en el caso de reclamación de sanciones, los tribunales siempre terminan siempre reenviando el expediente a la Superintendencia del Medio Ambiente tras la sentencia favorable $e^{76}$, lo cual puede generar consecuencias prácticas perniciosas: que la segunda sanción sea nuevamente impugnada, derivando en una continua judicialización del procedimiento administrativo sancionatorio ${ }^{77}$.

La novedosa regulación de la Ley $N^{\circ} 20.600$, entonces, adolece de una grave incoherencia de diseño. Pese a que los tribunales ambientales cuentan con características de diseño (i.e. la especialización de sus jueces y sus competencias exclusivas) que le entregan incentivos institucionales suficientes como para no guardar deferencia con las decisiones ambientales que ha adoptado antes la Administración, sus competencias revisoras operan como

\footnotetext{
72 Hunter Ampuero 2015, 651-652.

${ }^{73}$ Ley $\mathrm{N}^{\circ} 20.600$, art. 30, inc. $1^{\circ}$.

74 Valdivia Olivares 2015, 268-269 (sosteniendo que los poderes que le confiere "son extremadamente fuertes" en tanto permiten "al juez impartir órdenes directas a la Administración, orientando (con precisión) su actuar").

75 Ley $\mathrm{N}^{\circ} 20.600$, art. 30, inc. $2^{\circ}$.

76 Méndez OrTiz 2018, 545 (planteando que "nuestros tribunales han entendido en forma tácita que la imposición de sanciones por parte de la SMA constituye un acto de contenido discrecional y, por tanto, sujeta a la restricción del artículo 30 , inciso $2^{\circ}$ de la Ley $N^{\circ} 20.600$. Ello ha llevado a que los tribunales ambientales, en caso de sentencias favorables al actor, se limiten a anular la resolución sancionatoria e impartan órdenes directas a la Superintendencia del Medio Ambiente tales como enmendar sus resoluciones sancionatorias con el fin de subsanar los vicios que derivaron en la nulidad del acto impugnado, o a retrotraer procedimientos sancionatorios o de fiscalización".)

77 El caso de Minera Pascua-Lama es bastante ilustrativo. Una de las primeras sanciones impuestas por la SMA tras la entrada en vigencia de sus facultades legales fue la impuesta en este caso, en mayo de 2013 (Resolución Exenta N 477/2013). Esta resolución fue reclamada ante el Segundo Tribunal Ambiental de Santiago por terceros opositores (Cruz y otros con SMA (2014a)), donde fue acogida, reenviando el expediente a la SMA para dictar una segunda resolución sancionatoria. La Corte Suprema confirmó dicha sentencia, por razones formales (Cruz y otros con SMA (2014b). Tras la reapertura, la SMA dictó finalmente la segunda resolución sancionatoria (Resolución $N^{\circ}$ 72/2018) en enero de 2018, la que igualmente fue reclamada, esta vez, ante el Primer Tribunal Ambiental. El tribunal dictó la sentencia acogiendo parcialmente las reclamaciones en septiembre de 2018, ordenando (por segunda vez) reenviar el expediente a la SMA (Compañía Minera Nevada SpA con SMA (2020)).
} 
obstáculo ${ }^{78}$. Las limitadas potestades del tribunal para dictar el acto de reemplazo -al menos, en materia sancionatoria- restringe en forma considerable el margen de revisión de parte de la judicatura.

En contraste, aunque la construcción jurisprudencial gestada al alero de la Ley $N^{\circ} 18.410$ asume la forma de una revisión cerrada y enfocada en el expediente, le entrega amplias potestades al juez para dictar actos de reemplazo. Como se ha visto, la Corte Suprema ha entendido que el juez puede emitir un acto en aquellos casos de vicios verificados en el mismo acto sancionatorio.

Esta breve comparación entre el modelo generado bajo la Ley $N^{\circ} 18.410$ con el creado legalmente en la Ley $N^{\circ} 20.600$ para los tribunales ambientales, lleva a concluir una paradoja: con un modelo contencioso-administrativo en materia eléctrica que es precario en términos de su regulación, se han alcanzado resultados que, desde un punto de vista de diseño institucional, son más coherentes que el modelo existente bajo los tribunales ambientales. El modelo de revisión de sanciones eléctricas permite una diferenciación de funciones entre la Administración y el tribunal revisor: una corte generalista que contará con incentivos para guardar deferencia a la labor técnica de la SEC. En contraposición, un modelo más reciente como el generado para los tribunales ambientales (por la Ley $\mathrm{N}^{\circ} 20.600$ ) adolece de incongruencias internas: encomienda la revisión judicial a un organismo especializado (lo cual, en principio, importa una duplicación de labores entre Administración y tribunal); pero, al mismo tiempo, le priva de competencias para dictar un acto sancionatorio de reemplazo, obligándolo a reenviar siempre y en cada caso el expediente a la Administración. Esto, por tanto, debe ser tomado como una luz de alerta para una idea imperante en nuestro medio: que la sola instauración de tribunales especiales en nuestro medio constituye per se una gran solución a los problemas existentes en materia de revisión judicial económica.

\section{Conclusiones}

El sistema de revisión judicial de sanciones eléctricas creado por la Ley $N^{\circ} 18.410$ adolece de las mismas deficiencias regulatorias que exhibe el panorama general de los contenciosos-administrativos en Chile: una carencia de reglas procesales, que se traduce en (1) una omisión de la forma en que el juez debe revisar el expediente que ha construido la Administración y (2) las competencias del juez en caso de una sentencia favorable. Esta situación ha derivado que la Corte Suprema haya sido la llamada a integrar estas lagunas, en una "jurisprudencia con poder normativo".

\footnotetext{
78 No deja de ser paradójico, por lo demás, que antes de la creación de los tribunales ambientales, los jueces ordinarios -encargados de la revisión de las sanciones ambientales impuestas por la autoridad administrativa- tuviesen facultades para modificar las sanciones impuestas por la Administración, y ahora, los tribunales ambientales carezcan de ellas.
} 
En los últimos años, respecto al primer punto, la Corte Suprema ha ido cristalizando un modelo de revisión cerrada caracterizado en cuatro criterios. Primero, el reclamo de ilegalidad de la Ley № 18.410 es de derecho estricto, sin que el juez pueda variar la fijación de los hechos que ya fue construida por la Administración. Segundo, como consecuencia de lo anterior, la apertura de un probatorio en el contencioso-administrativo -prevista en el artículo 19- es "una facultad del tribunal revisor". Esto genera dos consecuencias en la sede administrativa: Tercero, que es la SEC quien tiene que soportar la carga de la prueba (i.e. la ocurrencia de los hechos que configuran la infracción), y cuarto, que en el procedimiento administrativo -a diferencia del contencioso- la apertura del probatorio es una obligación, y no una mera facultad con que cuente la SEC. Respecto al segundo punto, la Corte Suprema ha permitido que los tribunales dicten un acto sancionatorio de reemplazo en casos de ilegalidades verificadas en el acto terminal (i.e. problemas de calificación de la infracción, falta de motivación). De modo que si los vicios se manifiestan en el procedimiento, corresponderá el reenvío a la SEC para que sea esta quien los subsane y dicte el acto de reemplazo.

Hay dos ventajas que presenta este modelo de revisión cerrada. Este modelo permite una especialización de funciones entre órganos administrativos y tribunales de justicia, evitando la fricción institucional y la duplicación de esfuerzos. Además, evita lo que en la literatura comparada se conoce como "sandbagging" (i.e. que el particular reserve prueba para producirla solo ante el tribunal revisor, haciendo inoficiosa la instancia administrativa). En suma, el modelo contencioso-administrativo construido bajo las reglas de la Ley N $N^{\circ} 18.410$ cuenta -con sus críticas y desventajas- con una coherencia interna que permite optimizar las funciones de cada foro. La construcción de los hechos quedará a cargo de la SEC, mientras que la corte revisora contará con competencias amplias para revisar la calificación de los hechos y las cuestiones de derecho planteadas por el particular (i.e. reclamante).

Con sus deficiencias, este sistema incluso es más coherente y óptimo que otros más recientes, como el creado por la Ley $N^{\circ} 20.600$ para los tribunales ambientales. Estos tribunales adolecen de ciertas incongruencias: se encarga la revisión a un tribunal de competencia exclusiva y excluyente en temas ambientales, y conformado por miembros especialistas en el área, lo cual podría derivar en fricciones institucionales y duplicación de esfuerzos con una consecuente demora en la tramitación del reclamo judicial ${ }^{79}$. Al mismo tiempo, se les priva de la posibilidad de dictar actos de reemplazo, obligándolos siempre a reenviar el expediente a la Administración. El modelo contencioso-administrativo en materia eléctrica es precario en términos de su regulación, pero ello no le ha impedido alcanzar resultados que desde un punto de

\footnotetext{
79 Especialmente bajo un marco normativo que guarda silencio frente al estándar de revisión. Si los jueces son especialistas, tienen incentivos para realizar una revisión exhaustiva de lo obrado en la Administración, generando, en definitiva, en una prolongación considerable del contencioso-administrativo.
} 
vista de diseño institucional son más coherentes que el modelo existente bajo los tribunales ambientales. Esto, por último, debe ser tomado como una luz de alerta para una idea imperante en nuestro medio: que la sola instauración de tribunales especiales en nuestro medio constituye per se una gran solución a los problemas existentes en materia de revisión judicial económica.

\section{Bibliografía citada}

Aróstica Maldonado, Iván (1987). Algunos problemas del Derecho Administrativo Penal. Revista de Derecho (Universidad de Concepción) 55(182), 71-81.

Aróstica Maldonado, Iván (1991). Un lustro de sanciones administrativas (1988-1992). Revista de Derecho Público (Universidad de Chile) (50), 173-195.

Asımow, Michael (2015). Five models of administrative adjudication. The American Journal of Comparative Law 63, 3-32.

Asimow, Michael y Dotan, Yoav (2016). Open and closed judicial review of agency action. The American Journal of Comparative Law 64, 521-554.

Bermúdez Soto, Jorge (2011). Derecho Administrativo General ( $2^{a}$ ed.). Legal Publishing.

Bernedo Pinto, Patricio (2013). Historia de la Libre Competencia en Chile. 1959-2010. Fiscalía Nacional Económica.

Bordali Salamanca, Andrés (2005). Principios de una nueva justicia administrativa en Chile. En Juan Carlos Ferrada Bórquez (Coord.), La Nueva Justicia Administrativa (pp. 341381). LexisNexis.

Carmona Santander, Carlos (2005). El contencioso-administrativo entre 1990 y 2003. En Juan Carlos Ferrada Bórquez (Coord.), La Nueva Justicia Administrativa (pp. 183-240). LexisNexis.

Cordero Vega, Luis (2016). Lecciones de Derecho Administrativo. Legal Publishing.

Cordero Vega, Luis (2020). El Derecho Administrativo chileno. Crónicas desde la jurisprudencia. DER Editores.

CURRIE, David y GOODMAN, Frank (1975). Judicial review of federal administrative action: Quest for the optimum forum. Columbia Law Review, 75(1), 1-88.

Duguit, León (2007) [1913]. Las Transformaciones del Derecho Público y Privado. Edit. Comares.

Esteve Pardo, José (2017). Lecciones de Derecho Administrativo (7 ${ }^{\text {a }}$ ed.). Marcial Pons.

ERnST, Daniel (2014). Tocqueville's Nightmare. The Administrative State Emerges in America, 1900-1940. Oxford University Press.

Ferrada Bórouez, Juan Carlos (2011). Los procesos administrativos en el Derecho chileno. Revista de Derecho de la Pontificia Universidad Católica de Valparaíso, 36, 251-277.

Ferrada Bórouez, Juan Carlos (2012). El sistema de justicia administrativa chileno: revisión de la legalidad de actos administrativos o protección de derechos y/o intereses. Revista de Derecho (Valdivia), 25(1), 103-126.

Ferrada Bórouez, Juan Carlos (2014). La articulación de potestades administrativas y jurisdiccionales en la aplicación de sanciones administrativas en el Derecho chileno: poderes distintos, pero complementarios. En Jaime Arancibia Mattar y Pablo Alarcón Jaña (Coords.), Sanciones Administrativas (pp. 239-261). Legal Publishing.

Ferrada BórQuez, Juan Carlos (2016). La clasificación de los recursos o acciones contencioso-administrativas en el Derecho Administrativo chileno: la influencia de la doctrina francesa en nuestro derecho y su aplicación jurisprudencia. En Juan Carlos Ferrada Bórquez, Jorge Bermúdez Soto y Osvaldo Urrutia Silva (Eds.), Doctrina y Enseñanza del Derecho Administrativo Chileno: Estudios en Homenaje a Pedro Pierry Arrau (pp. 321341). Ediciones Universitarias de Valparaíso.

Garcia de Enterría Martínez-Carande, Eduardo (2007). Las Transformaciones de la Justicia Administrativa: de Excepción Singular a la Plenitud Jurisdiccional. ¿Un cambio de Paradigma? Edit. Aranzadi.

García de Enterría Martínez-Carande, Eduardo y Fernandez Rodriguez, Tomás-Ramón (2017). Curso de Derecho Administrativo (Tomo II). Aranzadi. 
Hunter Ampuero, Iván (2015). La carga de la prueba en el contencioso administrativo ambiental chileno: notas a propósito de la ley de tribunales ambientales. Revista Chilena de Derecho 42(2), 649-669.

Jara Schnettler, Jaime (2018). La revisión jurisdiccional de las sanciones administrativas y la garantía del recurso de plena jurisdicción. Revista de Derecho Público (89), 59-91.

LARROCAU TORRES, Jorge (2019). El control judicial de la fuerza probatoria del expediente administrativo. En María Elena Santibáñez Torres (Dir.) y Ximena Marcazzolo Awad (Coord.), La prueba en los procedimientos. VII Jornadas Nacionales de Derecho Procesal (pp. 643-677). Legal Publishing.

Méndez Ortiz, Pablo (2017). Tribunales Ambientales y Contencioso-Administrativo. Edit. Jurídica.

Méndez Ortiz, Pablo (2018). La precariedad del contencioso ambiental. lus et Praxis 24(3), 525-552.

MeRRILL, Thomas W. (2011). Article III, agency adjudication, and the origins of the appellate review model of Administrative Law. Columbia Law Review 111(5), 939-1003.

Poblete ItURRATE, Orlando (2016). Procedimiento administrativo sancionador y enjuiciamiento posterior de la Administración. En Jaime Arancibia Mattar y Alejandro Romero Seguel (Coords.), La prueba en la litigación pública (pp. 15-82). Librotecnia.

Reyes Poblete, Miguel Ángel (2014). Debido proceso y litigación pública: Problemáticas relativas a la prueba en lo sancionatorio administrativo. En Jaime Arancibia Mattar y Pablo Alarcón (Coords.), Sanciones Administrativas (pp. 325-342). Legal Publishing.

Romero Rodríguez, Sophía (2019). Consideraciones constitucionales en la formación del expediente administrativo y su uso como fuente de prueba en el proceso contencioso-administrativo. En María Elena Santibáñez Torres (Dir.) y Ximena Marcazzolo Awad (Coord.), La prueba en los procedimientos. VII Jornadas Nacionales de Derecho Procesal (pp. 423-466). Legal Publishing.

Romero Seguel, Alejandro (2004). La jurisprudencia de los tribunales como fuente del derecho. Ed. Jurídica de Chile.

Santibáñez Yáñez, Francisco (2016). Límites a la prueba en el contencioso-administrativo chileno: criterios jurisprudenciales. En Jaime Arancibia Mattar y Alejandro Romero Seguel (Coords.), La prueba en la litigación pública (pp. 139-160). Librotecnia.

Sото KLoss, Eduardo (2005). La potestad sancionadora de la Administración, ¿se adecúa a la Constitución? En Sanciones Administrativas y Derechos Fundamentales (pp. 29-49). Universidad Santo Tomás.

Sото Delgado, Pablo (2018). El giro conservador en torno a las sanciones administrativas por obra del Tribunal Constitucional de Chile: Transformando a la Administración en juez para desproteger el interés público. Revista de la Facultad de Derecho (Universidad de La República, Uruguay) (45), 1-49.

Silva Cimma, Enrique (1994). Derecho Administrativo Chileno y Comparado (Tomo III. El Control Público). Ed. Jurídica de Chile.

Tapia Canales, Javier y Cordero Vega, Luis (2015). La revisión judicial de las decisiones regulatorias: Una mirada institucional. Estudios Públicos (139), 7-65.

Valdivia Olivares, José Miguel (2015). Reflexiones sobre las acciones en Derecho Administrativo. En Adrián Schopf Olca y Juan Caros Marín González (Eds.), Lo Público y lo Privado en el Derecho. Estudios en Homenaje al Profesor Enrique Barros Bourie (pp. 349-431). Thomson Reuters.

Valdivia Olivares, José Miguel (2017). Contenido y efectos de las sentencias de los tribunales ambientales. En Juan Carlos Ferrada Bórquez, Jorge Bermúdez Soto y Francisco Pinilla Rodríguez (Coords.), La Nueva Justicia Ambiental (pp. 253-276). Thomson Reuters.

\section{Jurisprudencia citada}

Arcos y Cía Ltda. con SEC (2019): Corte Suprema, 26 de agosto de 2019 (Rol No 9.2342019), Sala $3^{\circ}$ [apelación reclamo de ilegalidad]. 
CGR Distribución S.A. con SEC (2016): Corte Suprema, 19 de octubre de 2016 (Rol $N^{\circ}$ 47.898-2016), Sala $3^{\circ}$ [apelación reclamo de ilegalidad].

Chilectra S.A. con SEC (2017a): Corte Suprema, 23 de agosto de 2017 (Rol No 19.0582017), Sala $3^{\circ}$ [apelación reclamo de ilegalidad].

Chilectra S.A. con SEC (2017b): Corte Suprema, 17 de marzo de 2017 (Rol N 97.7372016), Sala $3^{\circ}$ [apelación reclamo de ilegalidad].

Chilquinta Energía con SEC (2017): Corte Suprema, 25 de octubre de 2017 (Rol No 21.8142017), Sala $3^{\circ}$ [apelación reclamo de ilegalidad].

Compañía Minera Nevada SpA con SMA (2020): Primer Tribunal Ambiental, 17 de septiembre de 2020 (Rol N R-5-2018), sin sala [reclamo de ilegalidad]

Cruz y otros con SMA (2014a): Segundo Tribunal Ambiental, 3 de marzo de 2014 (Rol $N^{\circ}$ R-6-2013), sin sala [reclamo de ilegalidad].

Cruz y otros con SMA (2014b): Corte Suprema, 30 de diciembre de 2014 (Rol No 11.6002014), Sala $3^{\circ}$ [casación].

Dimarsa Ltda. con SEC (2019): Corte Suprema, 10 de febrero de 2019 (Rol 34.073-2019). Sala $3^{\circ}$ [apelación reclamo de ilegalidad].

Enel Distribución con SEC (2019): Corte Suprema, 29 de julio de 2019 (Rol N 7.290-2019), Sala $3^{\circ}$ [apelación reclamo de ilegalidad].

Enel Distribución con SEC (2020): Corte Suprema, 20 de abril de 2020 (Rol No 36.7232019). Sala $3^{\circ}$ [apelación reclamo de ilegalidad].

INGCER S.A. con SEC (2019): Corte Suprema, 8 de noviembre de 2019 (Rol N²2.1962019), Sala $3^{\circ}$ [apelación reclamo de ilegalidad].

Inmobiliaria Los Coihues con SEC (2019): Corte Suprema, 20 de octubre de 2019 (Rol $N^{\circ}$ 13.324-2019), Sala $3^{\circ}$ [apelación reclamo de ilegalidad].

Luz Linares con SEC (2017): Corte Suprema, 25 de mayo de 2017 (Rol № 100.726-2016), Sala $3^{\circ}$ [apelación reclamo de ilegalidad].

Metrogas S.A. con SEC (2020): Corte Suprema, 20 de abril de 2020 (Rol No 36.474-2019). Sala $3^{\circ}$ [apelación reclamo de ilegalidad].

Miguelez con SEC (2019): Corte Suprema, 7 de julio de 2019 (Rol N²0.497-2018), Sala 3º [apelación reclamo de ilegalidad].

Naser con SEC (2020): Corte Suprema, 28 de julio de 2020 (Rol №33.230-2019). Sala $3^{\circ}$ [apelación reclamo de ilegalidad].

Sánchez y Sánchez con SEC (2020): Corte Suprema, 8 de mayo de 2020 (Rol N 34.0162019), Sala $3^{\circ}$ [apelación reclamo de ilegalidad].

SEC con Enel Distribución Chile (2019): Corte Suprema, 21 de marzo de 2019 (Rol $N^{\circ}$ 16.477-2018), Sala $3^{\circ}$ [apelación reclamo de ilegalidad].

Sistema de Transmisión del Sur S.A. con SEC (2019): Corte Suprema, 30 de enero de 2019 (Rol No 19.158-2018), Sala $3^{\circ}$ [apelación reclamo de ilegalidad].

Suárez con SEC (2019): Corte Suprema, 8 de enero de 2019 (Rol №38.817-2017), Sala 3 [apelación reclamo de ilegalidad].

Transelec con SEC (2019): Corte Suprema, 14 de mayo de 2019 (Rol № 186-2019), Sala $3^{\circ}$ [apelación reclamo de ilegalidad]. 